\title{
Different milk feeding intensities during the first 4 weeks of rearing dairy calves: Part 2: Effects on the metabolic and endocrine status during calfhood and around the first lactation
}

\author{
J. Kesser, ${ }^{*}$ M. Korst, ${ }^{*} †$ C. Koch,† F.-J. Romberg,† J. Rehage,‡ U. Müller, ${ }^{*}$ M. Schmicke,‡ K. Eder,§ \\ H. M. Hammon,\# H. Sadri, ${ }^{*}$ and H. Sauerwein ${ }^{* 1}$ \\ *Institute of Animal Science, Physiology \& Hygiene Unit, University of Bonn, Bonn 53115, Germany \\ †Educational and Research Centre for Animal Husbandry, Hofgut Neumuehle, Muenchweiler a.d. Alsenz 67728, Germany \\ ¥University of Veterinary Medicine, Foundation, Hannover 30559, Germany \\ §Institute of Animal Nutrition and Nutritional Physiology, Justus-Liebig University, Giessen 35392, Germany \\ \#Leibniz Institute for Farm Animal Biology, Dummerstorf 18196, Germany
}

\section{ABSTRACT}

Feeding dairy calves at high intensity has been demonstrated to increase milk yield in later life. We investigated the effect of 3 different feeding regimens in the preweaning period on the metabolic and endocrine status during calfhood and in heifers at the onset of the first lactation. In trial 1, 57 German Holstein calves were allocated to 3 different feeding groups: milk replacer restricted to $6.78 \mathrm{~kg} /$ calf per day, $11.5 \%$ solids (MR-res, $\mathrm{n}=20$ ), milk replacer $13.8 \%$ solids, ad libitum (MR-ad lib, $\mathrm{n}=17$ ), and whole milk ad libitum (WM-ad lib, $\mathrm{n}=20$ ). All calves received ad libitum colostrum for 3 d postnatal (p.n.). From d 4 to 27, all calves were fed according to their respective feeding regimen, resulting in average intakes of $6.38,9.25$, and $9.47 \mathrm{~kg} / \mathrm{d}$ in MR-res, MR-ad lib, and WM-ad lib, respectively. Thereafter, all calves were fed according to the MR-res regimen until weaning at d 55 (gradually until d 69 p.n.). Blood samples were collected on d 0 before colostrum intake and on d 1, 3, 11, 22, 34, 43, 52, 70, 90, and 108 p.n. Liver biopsies were taken on d 19 and 100, and on d 22, 52, and 108 p.n. intravenous glucose tolerance tests were performed. The male calves ( $\mathrm{n}=8$ to 10 per group) underwent also an insulin tolerance test on d 24, 54, and 110 p.n. The females $(\mathrm{n}=28)$ from trial 1 were further reared and bred as common practice, and were enrolled in trial 2 when beginning the last trimester of pregnancy. Blood samples were collected monthly antepartum starting 91 $\mathrm{d}$ before calving and weekly $(0-70 \mathrm{~d})$ postpartum. Trial 1 was subdivided into 4 phases (P): P0 (d 0-1), P1 (d 2-27), P2 (d 28-69), and P3 (d 70-110 p.n.). In trial

Received June 12, 2016.

Accepted October 18, 2016.

${ }^{1}$ Corresponding author: sauerwein@uni-bonn.de
1 , the leptin and adiponectin concentrations increased with colostrum intake. Differences in fatty acids, insulin, adiponectin, revised quantitative insulin sensitivity check index (RQUICKI), and variables from the glucose tolerance tests were largely limited to P1. The MR-res group had greater RQUICKI and fatty acid values, and lower insulin and, as a trend, adiponectin concentrations than in 1 or both ad lib groups. These differences were partly sustained in P2 (fatty acids, adiponectin, and RQUICKI) and in P3 (adiponectin). The hepatic mRNA abundance of the gluconeogenic enzymes phosphoenolpyruvate carboxykinase and pyruvatcarboxylase increased from d 19 to 100. None of the blood variables were different between the groups when tested in pregnancy and lactation. Our results do not support a sustained deflection of metabolic regulation by rearing at different feeding intensities; nevertheless, the differences observed during rearing might influence nutrient utilization in later life or the cellular development of organs, such as the mammary gland, and thereby affect milk yield. Further studies involving greater animal numbers and, thus, improved power will help to sort out the mechanisms of programming body function in later life via nutrition in early life.

Key words: dairy calf, metabolic programming, insulin sensitivity, adiponectin, RQUICKI

\section{INTRODUCTION}

Metabolic programming is defined as a permanent or long-lasting change in the structure or function of an organism arising from a stimulus or insult that acts during a sensitive or critical period in early life (Lucas, 1991). In dairy cows, nutrition during fetal or neonatal life can influence health and performance in later life (Bach, 2012). Feeding increased amounts of whole milk or milk replacer in the first weeks of rearing 
was reported to increase milk yield in the first lactation as compared with the common practice of feeding calves restrictively (Shamay et al., 2005; Moallem et al., 2010). In addition, increased growth rates due to increased intakes of concentrate in the first months of life were positively correlated with later milk yields (Bach and Ahedo, 2008; Heinrichs and Heinrichs, 2011). A meta-analysis of 12 studies on the topic demonstrated that long-term productivity benefitted from increased nutrient intake from milk or milk replacer during the preweaning period; those authors also stated that many studies were underpowered to appropriately test such effects (Soberon and van Amburgh, 2013).

The current concepts regarding the mechanisms underlying increased milk yield in intensively reared dairy calves mainly comprise 3 different aspects: (1) improved gastrointestinal function and liver metabolism resulting in greater feed digestibility and better nutrient utilization (Baldwin et al., 2004; Khan et al., 2011); (2) stimulated development of the mammary parenchyma, which may in turn give rise to a greater capacity for milk production (Brown et al., 2005; Geiger et al., 2016); and (3) tuning of the endocrine regulation of metabolism in favor of milk synthesis in later life. In the latter context, insulin and insulin sensitivity are of central importance; the reduced insulin sensitivity of peripheral tissues observed in late pregnancy and early lactation facilitates the partitioning of nutrients, in particular glucose, toward the mammary gland, in which glucose uptake is largely independent of insulin (Bell and Bauman, 1997). Evidence from both animal models and epidemiological studies in humans shows that early nutrition may affect insulin action in later life (Martin-Gronert and Ozanne, 2012; Duque-Guimarães and Ozanne, 2013). Results from rat studies suggest that the early environment can also affect $\beta$-cell mass and function and, hence, insulin secretion (TarryAdkins and Ozanne, 2011). Intensive feeding of male Holstein calves during the first 3 wk of life has been demonstrated to increase the numbers of islets of Langerhans and the circulating concentrations of insulin at 8 mo of age (Prokop et al., 2015). In the current study, we focused on the endocrine and metabolic alterations potentially induced by the feeding regimen in early life. We hypothesized that intensive feeding during the first 4 wk of life will elicit sustained changes of metabolic hormones that will continue until lactation and promote milk production. In addition, we hypothesized that ad libitum feeding of whole milk will be more effective to yield a metabolic profile in favor of milk production as compared with milk replacer. To test these hypotheses and to elucidate the mode of action of the beneficial effects reported for intensive feeding of dairy calves during the first weeks of life on their later lactational performance, we aimed (1) to characterize their metabolic and endocrine status during differential feeding (d 4-27 of life), and (2) to evaluate whether potential differences might be sustained until d 110 of life and also during late pregnancy (last trimester) and the first $70 \mathrm{~d}$ of lactation.

\section{MATERIALS AND METHODS}

The animal experiments were performed in strict accordance with the German Law for the Protection of Animals and were approved by the relevant authority (Landesuntersuchungsamt Rheinland-Pfalz, Koblenz, Germany; G 11-20-026). Two trials were conducted. Trial 1 was focused on the effects of different preweaning feeding regimens in calves. In trial 2, the female calves from trial 1 were studied as heifers during late pregnancy and the first $70 \mathrm{~d}$ of lactation. Both trials were performed at the Educational and Research Centre for Animal Husbandry, Hofgut Neumuehle, Muenchweiler a.d. Alsenz, Germany. The experimental design and the gross outcomes in terms of performance are presented in the companion paper by Korst et al. (2017). The experimental designs are described in brief in the following sections.

\section{Trial 1}

German Holstein calves (29 females and 28 males) were studied from April 2012 to January 2013 during their first $110 \mathrm{~d}$ of life. All calves were born spontaneously at term and received colostrum milked from their dam within $2 \mathrm{~h}$ after birth via a teat bucket in the calving pen next to their dam. The calves were then transferred to individual straw-bedded hutches (Flixbox, Mayer Maschinenbaugesellschaft mbH, Tittmoning, Germany) and fed twice daily by a teat bucket with colostrum from their dam for the first $3 \mathrm{~d}$ of life. The amounts offered per meal were sized to exceed the actual intake; the latter was quantified by subtracting the residual milk from the total amount offered per meal. The mean colostrum intake in the subsequently formed feeding groups was not different; the average daily intake during the 3 -d colostrum phase was 5,982 $\pm 176 \mathrm{~g}$ (mean $\pm \mathrm{SEM}$ ). The differential feeding was started on d 4 postnatal (p.n.). The calves were randomly allocated to 3 different feeding groups balanced for sex and BW: one received milk replacer (MR; Neumühle sauer, Trouw Nutrition Deutschland GmbH, Burgheim, Germany) restricted to a maximum of 6.78 $\mathrm{kg} / \mathrm{d}$ (MR-res; $11.5 \%$ solids; $\mathrm{n}=20$, each 10 males and females); the second group had ad libitum access to MR (MR-ad lib; $13.8 \%$ solids; $\mathrm{n}=17,8$ males and 9 females); and the last group had ad libitum access to 
whole milk [WM-ad lib; acidified tank milk, $1 \mathrm{~mL}$ of Schaumacid/L (H. W. Schaumann GmbH, Pinneberg, Germany) supplemented with a mix of trace elements and vitamins $(1 \mathrm{~mL} / \mathrm{L}$ of Milkivit Quick-Mix/L, Trouw Nutrition Deutschland $\mathrm{GmbH}) ; \mathrm{n}=20,10$ males and 10 females]. From d 8 until 69 p.n., the calves were kept in straw-bedded group pens with an automatic feeding system (Vario Kombi, Förster-Technik GmbH, Engen, Germany). All groups had free access to hay and water from d 8 p.n. onwards, and concentrate was available for all calves from d 8 until 69 by an automatic feeding system (Vario Kombi). Differential feeding was continued until d 27 p.n. Thereafter, the calves of the MR-ad lib and WM-ad lib groups were gradually adapted (within $2 \mathrm{~d}$ ) to the feeding regimen of the MRres group; all calves continued on this regimen until d 55 p.n. until gradual weaning was done on d 69. From d 70 until the end of the trial at d 110 p.n., calves were housed in group pens and had free access to a TMR for milking cows (see companion paper; Korst et al., 2017).

Birth weight was recorded and, thereafter, the calves were weighed weekly and also before a tolerance test (see below) was performed. Health status and eventual medical treatments were recorded regularly. As illustrated in Figure 1, blood samples were taken immediately after birth (d 0$)$ before colostrum consumption and on $\mathrm{d} 1,3,11,22,34,43,52,70,90$, and 108 p.n. from the jugular vein and serum and plasma were prepared. All blood samples from $\geq 1 \mathrm{~d}$ p.n. were collected after the calves were suspended from access to liquid and solid feed $2 \mathrm{~h}$ before blood sampling. Samples were stored at $-20^{\circ} \mathrm{C}$ until analyses.

Liver biopsies were taken on d 19 and 100 p.n. After shaving, disinfection, and local anesthesia $(5 \mathrm{~mL}$ of Isocaine $2 \%$, Selectavet Dr. Otto Fischer GmbH, WeyarnHolzolling, Germany), a small incision was made with a scalpel between the 11th and the 12th rib on a line between the olecranon and the tuber coxae, and biopsies ( $\sim 50 \mathrm{mg}$ ) were obtained with sterile 14 -gauge biopsy needles (Dispomed Witt oHG, Gelnhausen, Germany). The samples were immediately snap-frozen in liquid nitrogen and stored at $-80^{\circ} \mathrm{C}$ until further analysis. After the biopsy, the puncture site was treated with antiseptic spray (Oxytetracycline spray blue, Bayer Health Care AG, Leverkusen, Germany).

In addition, i.v. glucose tolerance tests (GTT) were performed in all calves on d 22, 52, and 108 and i.v. insulin tolerance tests (ITT) were performed on d 24, 54 , and 110 in the male calves only. The protocols used were described earlier by Bossaert et al. (2009) and Oikawa and Oetzel (2006). At least $4 \mathrm{~h}$ before the tests, calves had no access to milk, hay, and TMR. For the GTT, the calves were i.v. infused with glucose $(150 \mathrm{mg} /$ $\mathrm{kg}$ of BW, Glucose 40\%, Selectavet Dr. Otto Fischer
$\mathrm{GmbH})$. Blood samples were collected from the jugular vein $-10,-5,4,8,12,18,25,36,45,60,90$, and 120 min relative to the glucose infusion. For the ITT, the calves were i.v. infused with $0.05 \mathrm{IU} / \mathrm{kg}$ of $\mathrm{BW}$ of human recombinant insulin (Actrapid Penfill, Novo Nordisk A/S, Bagsværd, Denmark) and blood was sampled at $-15,-5,15,30$, and 45 min relative to the infusion.

For testing the relationship between the concentration of adiponectin in colostrum and milk with the serum concentrations, we collected blood samples from 22 additional German Holstein calves before their first colostrum intake on d 0 and thereafter on $\mathrm{d} 1,2 \mathrm{~h}$ after the last colostrum feeding. In total (i.e., including the calves from trial 1), we had serum samples from these $2 \mathrm{~d}$ available from 79 calves. Colostrum from the day of calving and milk samples (7 DIM) from the respective dams $(\mathrm{n}=79)$ were also collected and all samples stored at $-20^{\circ} \mathrm{C}$ until analysis.

\section{Trial 2}

After finishing trial 1 , the heifer calves $(\mathrm{n}=28)$ were kept in straw-bedded group pens and had ad libitum access to a TMR for milking dairy cows and were then transferred to a loose-housing system with high boxes in the stable for the milking cows at 5 to $6 \mathrm{mo}$ of age. Upon reaching 15 mo of age, estrus detection was started using activity sensors (foot rescounter via Dairy

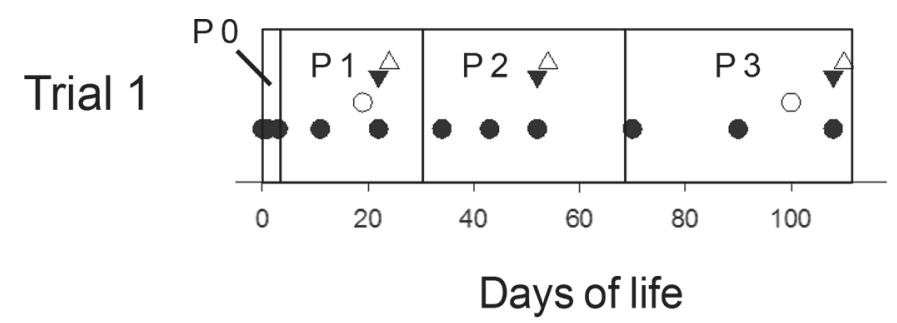

Trial 2

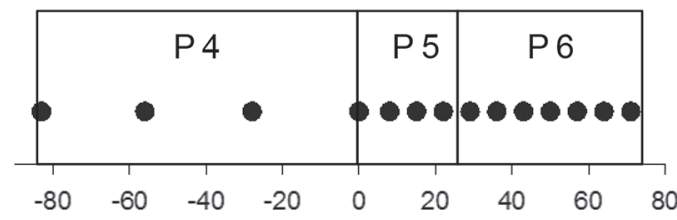

Days around calving

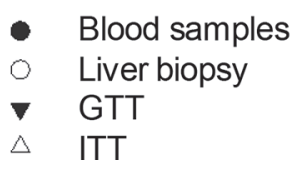

Figure 1. Sampling scheme in trial 1 and 2. Phases $(\mathrm{P}): \mathrm{P} 0=\mathrm{d}$ $0-1 ; \mathrm{P} 1=\mathrm{d} 2-27 ; \mathrm{P} 2=\mathrm{d} 28-69 ; \mathrm{P} 3=\mathrm{d} 70-110 ; \mathrm{P} 4=\mathrm{d}$ 91-30 ante partum; P5 = calving until d 21 postpartum; $\mathrm{P} 6=\mathrm{d} 28-70$ postpartum. GTT $=$ glucose tolerance test; ITT $=$ insulin tolerance test. 
Plan C 21, GEA Farm Technologies GmbH, Boenen, Germany) and visual observation. Pregnancies were confirmed by veterinary rectal palpation. On average, heifers were first inseminated at $15 \pm 1$ mo of age and received a TMR for dry cows until $21 \mathrm{~d}$ before expected calving, when they were integrated into the herd with the lactating dairy cows. During this time they had free access to the TMR for high-yielding dairy cows offered in weighing troughs (Insentec B. V., Marknesse, the Netherlands). The heifers were transferred to individual calving pens 5 to $7 \mathrm{~d}$ antepartum (a.p.). After calving, the calves were separated; the heifers were milked twice daily (0500 and $1530 \mathrm{~h}$ ) and kept in a group pen with ad libitum access to the TMR for the first $5 \mathrm{~d}$ postpartum (p.p.). For the remaining lactation, the heifers were returned to the weighing troughs and received a TMR for high-yielding cows.

Milk was sampled monthly over the first lactation (305 DIM) as combined aliquots from the evening and the next morning milking. Samples were stabilized with Bronopol (2-bromo-2-nitropropane-1,3-diol, SigmaAldrich, Taufkirchen, Germany) and transported to the regional laboratory of the milk-recording organization (Landeskontrollverband Rheinland-Pfalz-Saar e. V., Bad Kreuznach, Germany), where milk fat, protein, lactose, and SCC were analyzed via infrared analyzer (MilkoScan FT-6000, Foss Analytical A/S, Hillerød, Denmark).

Body weight was recorded every second month starting $111 \mathrm{~d}$ p.n. After calving, BW was recorded twice daily after milking via an automatic scale (GEA Farm Technologies GmbH). Health status and eventual medical treatments were recorded regularly. Blood samples were collected from the coccygeal vein monthly before the expected calving date (starting $91 \mathrm{~d}$ a.p.), at calving, and thereafter in weekly intervals until d 70 p.p.

\section{Analyses}

The concentrations of fatty acids, glucose, and BHB were determined in the serum samples obtained in both trials by an automatic spectrophotometer (ABX Pentra 400, Horiba ABX, SAS, Montpellier, France). In trial 1, we used kits for glucose (\#553-230, MTI Diagnostics, Idstein, Germany), fatty acids (\#434-91795, WAKO Chemicals GmbH, Neuss, Germany), and BHB (\# RB 1007, Randox Laboratories, Crumlin, UK). In trial 2, we used kits for glucose (\#A11A01667, Horiba ABX), fatty acids (\#434-91795, WAKO Chemicals GmbH), urea (\#LT-UR 0010, Labor + Technik, Berlin, Germany), and BHB (\# RB-1008, Labor + Technik). The concentration of total plasma protein (TPP) in the calf samples was measured by a hand-held refractometer
(RF.5612, Euromex Microscopen B.V., Arnhem, the Netherlands).

Hormone Analyses. For trial 1, RIA was used for determining the insulin concentrations (IM3210, Insulin IRMA KIT, Immunotech, Beckman Coulter, Brea, CA) as described previously (Schulz et al., 2015). The intra-assay coefficient of variation $(\mathbf{C V})$ was $7.6 \%$ and the interassay CV was $10.7 \%$; the limit of detection (LOD) was $3.95 \mu \mathrm{U} / \mathrm{mL}$.

For trial 2, insulin was measured via RIA for porcine insulin (PI-12K, Linco Research, St. Charles, MO) that was validated for bovine serum previously (Hammon et al., 2009). The intra-assay $\mathrm{CV}$ was $8.2 \%$ and the interassay CV was $4.3 \%$. The LOD was $1.61 \mu \mathrm{U} / \mathrm{mL}$ and the specificity for bovine insulin was $90 \%$.

Leptin in serum, colostrum, and milk was measured by an ELISA developed in-house (Sauerwein et al., 2004). The intra- and interassay CV were 3.6 and 7.8\%, respectively; the LOD was $0.3 \mathrm{ng} / \mathrm{mL}$. Adiponectin in serum, colostrum, and milk was measured by a modified ELISA, developed in-house, specific for bovine adiponectin (Mielenz et al., 2013; Kesser et al., 2015). Assay accuracy was confirmed by linearity and parallelism of diluted samples. The LOD was $0.03 \mathrm{ng} / \mathrm{mL}$; the intra- and interassay CV were 7 and $9 \%$, respectively.

mRNA Abundance of Enzymes in Liver Samples. Quantitative PCR was carried out using a Mx3000P cycler (Stratagene, Agilent Technologies, CA) after total RNA extraction and cDNA synthesis, as described earlier (Saremi et al., 2012). For quantitative $\mathrm{PCR}$, an inter-run calibrator and a negative template control were included in each run; for cDNA, a negative template control and a no reverse transcriptase control were included in each run. For each PCR reaction, a cDNA standard curve with serial dilutions was used to calculate efficiency-corrected relative quantities of the targets. Data were normalized with the geometric mean of the reference genes selected by $\mathrm{qBASE}^{\text {plus }} 2.0$ (Biogazelle, Ghent, Belgium) as described earlier (Hosseini et al., 2010). The 3 reference genes identified as the most stable were eukaryotic translation initiation factor 3, subunit K (EIF3K), low-density lipoprotein receptor-related protein 10 (LRP10), and hippocalcinlike (HPCAL1). The characteristics of the primers and the real-time PCR conditions are provided in Table 1.

\section{Calculations and Statistical Analyses}

For GTT, the means of concentrations from -10 and -5 min before the glucose infusion were considered as basal for glucose $\left(\mathrm{G}_{\mathrm{B}}\right)$ and insulin $\left(\mathrm{I}_{\mathrm{B}}\right)$, respectively. The difference between the basal and the peak concentrations was defined as $\Delta_{\text {Peak-Basis }}$. The area under 
the curve (AUC) was calculated with GraphPad Prism (GraphPad Software Inc., La Jolla, CA) using the increase of the glucose and insulin concentrations above the basal values until 120 min after the infusion.

For the ITT, the insulin-stimulated blood glucose response (ISBGR; \%) was calculated based on the equation of Oikawa and Oetzel (2006):

$$
\operatorname{ISBGR}(\%)=\left[\left(\mathrm{G}_{\mathrm{B}}-\mathrm{G}_{30}\right) / \mathrm{G}_{\mathrm{B}}\right] \times 100,
$$

where $\mathrm{G}_{\mathrm{B}}$ is the basal glucose concentration (calculated as the mean between the glucose concentration in the samples taken before the insulin infusion $(-10$ and -5 $\mathrm{min}$ ) and $\mathrm{G}_{30}$ is the glucose concentration at $30 \mathrm{~min}$ thereafter.

Insulin sensitivity was estimated by the revised insulin sensitivity check index (RQUICKI; Perseghin et al., 2001; Holtenius and Holtenius, 2007) according to the following equation:

$$
\begin{gathered}
\text { RQUICKI }=1 /[\log (\text { Glucose }, \mathrm{mg} / \mathrm{dL}) \\
+\log (\text { Insulin, } \mu \mathrm{U} / \mathrm{mL})+\log (\text { fatty acids, } \mathrm{mmol} / \mathrm{L})] .
\end{gathered}
$$

A low RQUICKI index indicates decreased insulin sensitivity.

For the statistical comparisons, data from trials 1 and 2 were divided into phases $(\mathbf{P})$. Phase $0=\mathrm{d} 0$ to 1 p.n.; $\mathrm{P} 1=\mathrm{d} 2$ to 27 p.n.; $\mathrm{P} 2=\mathrm{d} 28$ to 69 p.n.; $\mathrm{P} 3=\mathrm{d}$ 70 to 110 p.n. for trial 1. For trial 2, the phases were P4 $=\mathrm{d} 91$ to 30 a.p., $\mathrm{P} 5=$ calving until d 21 p.p.; $\mathrm{P} 6=\mathrm{d}$ 29 to 70 p.p. However, in trial 2, the number of animals that could be considered ( 28 in total; i.e., 9 to 10 per group) was insufficient to allow for an adequate power; therefore, results must be considered as preliminary.
Data were analyzed using the linear mixed model from SPSS version 22.0 (SPSS Inc., Chicago, IL). Normal distribution was tested by the Kolmogorov-Smirnov test and the Levene's test was used to test the homogeneity of variances. The linear mixed model with Bonferroni post hoc tests was used for the metabolite and hormone concentrations as dependent variables to identify group, time, and sex (only trial 1) differences. Group, sex, and time, as well as the interaction between group and time were included as fixed effects and the animal as random effect. Differences between groups at each time point were tested with an ANOVA (normal distributed and homogeneity of variance) or a Kruskal Wallis Test (not normal distributed and no homogeneity of variance). Student's $t$-test was used for the liver biopsies and the milk samples to identify differences between time points. Results are shown as means \pm standard error of the mean. Correlations were calculated by Spearman analysis $(\boldsymbol{\rho})$. Significant differences were declared at $P<0.05$ and trends at $P<0.1$.

\section{RESULTS}

\section{Growth Performance and Milk Yields}

Detailed information about performance data is presented in the companion paper (Korst et al., 2017). In brief, differences in BW, feed, and energy intake between the calves groups from trial 1 were observed mainly during P1. During this time, the calves in the MR-res group were lighter when compared with the ad libitum-fed animals. Whereas their consumption of concentrate at that time was numerically but not statistically higher, the energy intake from both liquid and

\begin{tabular}{|c|c|c|c|c|c|}
\hline Gene $^{1}$ & Sequences $\left(5^{\prime}-3^{\prime}\right)$ & $\begin{array}{l}\text { NCBI } \\
\text { Accession No. }\end{array}$ & bp & $\begin{array}{l}\text { Concentration } \\
\quad(\mathrm{n} M)\end{array}$ & $\begin{array}{l}\text { Annealing } \\
\left(\mathrm{s} /{ }^{\circ} \mathrm{C}\right)\end{array}$ \\
\hline \multicolumn{6}{|l|}{ EIF3K } \\
\hline Reverse & TTATACCTTCCAGGAGGTCCATGT & & & & \\
\hline \multicolumn{6}{|c|}{ 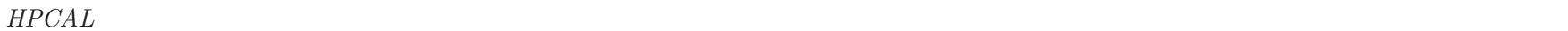 } \\
\hline Forward & CCATCGACTTCAGGGAGTTC & NM001098964 & 99 & 400 & $30 / 60$ \\
\hline Reverse & CGTCGAGGTCATACATGCTG & & & & \\
\hline Reverse & ATAGGGTTGCTGTCCCTGTG & & & & \\
\hline \multicolumn{6}{|c|}{ 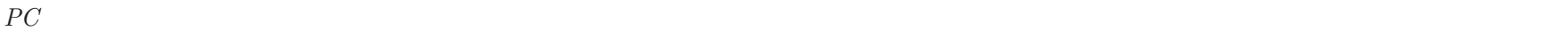 } \\
\hline Forward & ATCTCCTACACGGGTGACGT & NM_177946 & 214 & 1,000 & $30 / 60$ \\
\hline Reverse & TGTCGTGGGTGTGGATGTGCA & & & & \\
\hline \multicolumn{6}{|c|}{ 20 - } \\
\hline Forward & AACTCACGGTTCTGCACTCCA & NM_174737 & 229 & 800 & $30 / 60$ \\
\hline Reverse & GGTCGTGCATGATGACTTTGC & & & & \\
\hline
\end{tabular}
solid feed was only 60 and $80 \%$ of the ME intake in the

Table 1. Characteristics of primers and real-time PCR conditions

${ }^{1}$ EIF3 = eukaryotic translation initiation factor $3 ; H P C A L=$ hippocalcin-like $1 ; L R P 10=$ lipoprotein receptor-related protein $10 ; P C=$ pyruvate carboxylase; $P C K 1=$ (cytosolic) phosphoenolpyruvate carboxykinase. 
MR-ad lib and WM-ad lib groups, respectively. When all calves were fed according to the MR-res regimen for the remaining time of liquid feeding (P2), energy intakes with concentrate were greater in the WM-ad lib group than in the MR-ad lib group but were not different when compared with the MR-res group. At that time, the ADG of the MR-res group tended to greater values than in the MR-ad lib group, but was not different from the WM-ad lib group. At the end of trial 1 as well as in trial 2, these differences had disappeared. In trial 2, we found no differences in p.p. DMI, energy balance, BW, or milk composition. In addition, 305-d milk yield of heifers from the WM-ad lib group was numerically, but not statistically, greater than in the MR-res and the MR-ad lib group (765 and $153 \mathrm{~L}$, respectively).

\section{Metabolites}

The comparisons of the hormone and metabolite concentrations in the different phases of both trials are presented in Table 2. The time courses of the circulating concentrations of fatty acids, glucose, and BHB are shown for both the calves and the heifers in Figure 2. In trial 1 , the fatty acid concentration was lower in the MR-ad lib than in the MR-res and WM-ad lib group ( $P$ $<0.05$ ). From d 11 to 34 p.n., glucose concentrations in the MR-res group were lower $(P<0.05)$ than in the MR-ad lib and the WM-ad lib groups. The BHB concentration was greater in the MR-res than in the MRad lib group in trial 1 . We observed no sex differences for fatty acids, glucose, and BHB. The concentrations of TPP increased about 1.2 fold after the first intake of colostrum $(P<0.001)$ until d 3 p.n. We found no group or sex differences for TPP throughout the entire trial. In trial 2, the heifers originating from the different rearing protocols did not differ in fatty acids or glucose; only urea and BHB were different before parturition (P4). The WM-ad lib heifers had lower urea concentrations than the MR-res and MR-ad lib groups $(P=0.1$ and $P<0.05$, respectively) and tended to have lower BHB concentrations then the MR-ad lib group $(P=$ $0.1)$. Urea decreased around calving $(P<0.001)$ and increased toward the end of the trial $(P<0.001)$.

\section{Hormones}

The concentrations of adiponectin and insulin during both trials are shown in Table 2 and Figure 3. The MRres group tended $(P=0.07)$ to have lower adiponectin concentrations than the MR-ad lib group during trial 1. Female calves had greater adiponectin concentrations than male calves $(P=0.05)$. The MR-res group had lower $(P<0.05)$ insulin concentrations in blood than the WM-ad lib group in trial 1 . On d 11 and 22 p.n. the MR-res group had lower $(P<0.05)$ insulin concentrations than the MR-ad lib and the WM-ad lib groups. In trial 2, no significant group differences were observed for the insulin and adiponectin concentrations. The leptin concentrations, assessed only during trial 1, were not different between the feeding groups and are shown in Figure 4 with the mean leptin concentrations in colostrum and milk. The RQUICKI data are presented in Table 2 and Figure $3 \mathrm{C}$. The WM-ad lib group had lower RQUICKI values than the MR-res group $(P<$ $0.05)$; no group differences were observed in trial 2 .

\section{GTT and ITT}

The basal concentration, the peak concentration, $\Delta_{\text {Peak-Basis }}$, and the AUC of insulin and glucose measured during the GTT are presented in Table 3. Differences between the groups were limited to P1. The basal concentrations of glucose and insulin were lower in the MR-res than in the MR-ad lib and WM-ad lib groups $(P<0.05)$, and male calves tended to have greater basal insulin concentrations $(P<0.1)$. No differences were observed in the peak concentrations of glucose; however, the peak insulin concentration was lower in the MR-res than in the WM-ad lib group $(P<0.05)$. The $\Delta_{\text {Peak-Basis }}$ of glucose tended to be greater in the MR-res than in the MR-ad lib group $(P<0.01)$, and the $\Delta_{\text {Peak-Basis }}$ of insulin was lower in the MR-res than WM-ad lib group $(P<0.05)$. The AUC of insulin was lower in the MR-res than in the WM-ad lib group ( $P$ $<0.05$ ); however, no differences were observed in the AUC of glucose between groups and phases. In contrast, the AUC of glucose in male calves was greater than in female calves $(P<0.05)$. In Table 4 the ISBGR from the ITT (done in males only) is shown. Only in the MR-res group did we see a decrease of the ISBGR from P1 to P3 $(P<0.05)$. No differences between the groups were observed and only a numerical decrease from P1 to P3 in the ad libitum groups.

The mRNA abundances of PC and PCK1 are shown in Figure $5 \mathrm{~A}$ and $\mathrm{B}$. Both mRNA abundances increased from the first to the second biopsy $(P<0.01)$, but without any differences between the feeding groups or sexes.

In trial 1, we noted a positive correlation between the RQUICKI values and the adiponectin concentrations across all samples $(\rho=0.37 ; P<0.01)$. On d 0 , before the first intake of colostrum, RQUICKI values and adiponectin were negatively correlated $(\rho=-0.32 ; P<$ 0.05). This correlation changed to positive coefficients throughout the trial; on d 90 p.n. the correlation was $\rho$ $=0.42(P<0.01)$. In trial 2 , RQUICKI and adiponectin were not correlated. 


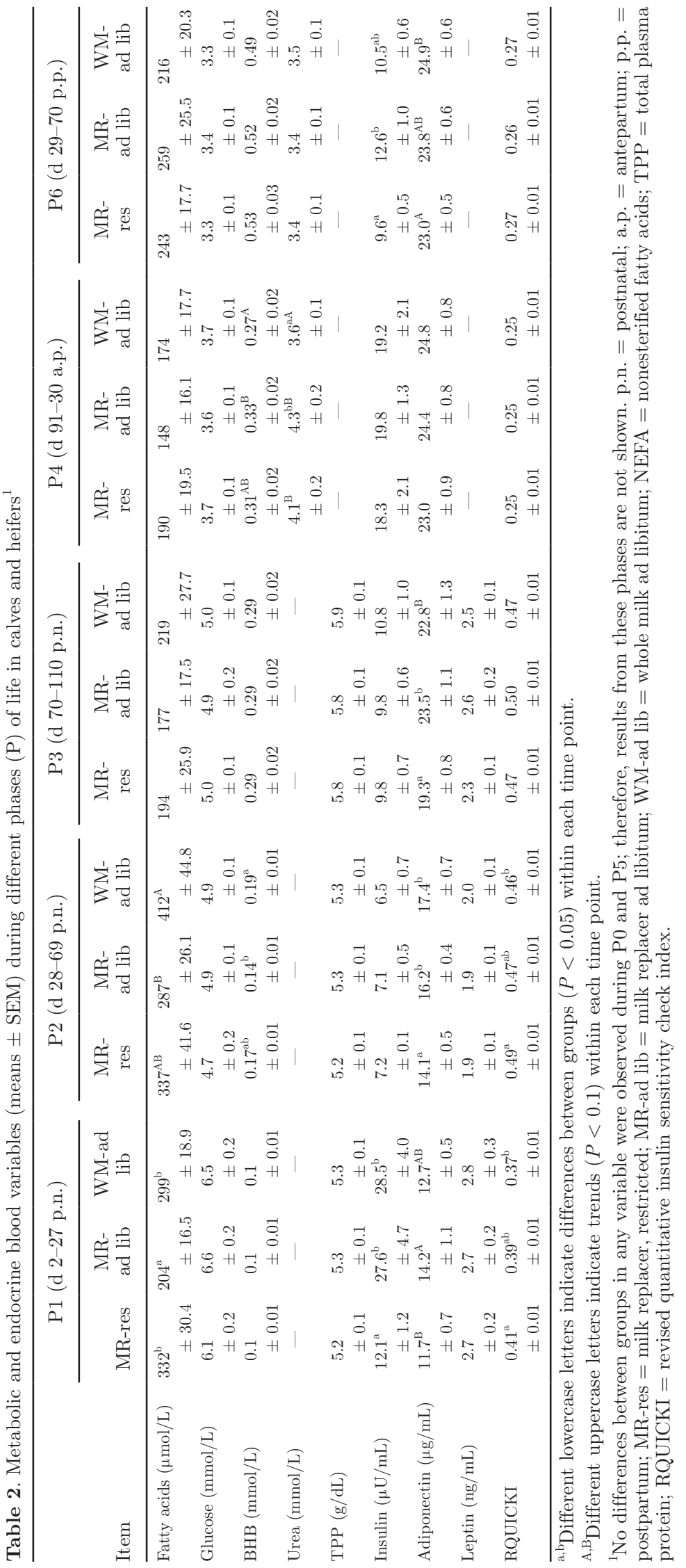



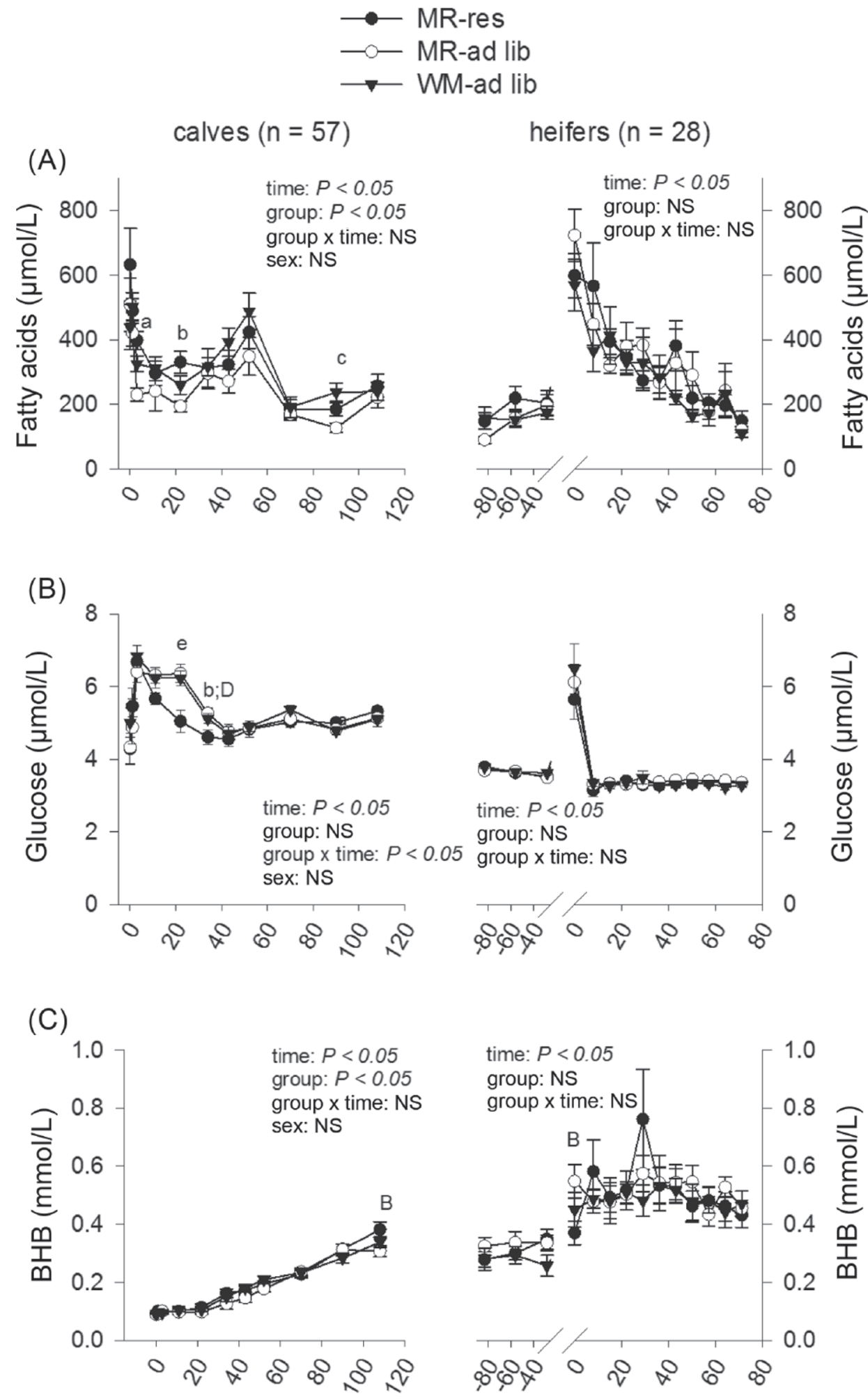

\section{Days of life}

Days around calving

Figure 2. Time-dependent changes (means \pm SEM) of fatty acids (A), glucose (B), and BHB (C) from trials 1 (calves) and 2 (heifers). Lowercase letters $(\mathrm{a}-\mathrm{c}, \mathrm{e})$ indicate differences between groups $(P<0.05)$; uppercase letters $(\mathrm{B}, \mathrm{D})$ indicate trends $(P<0.1)$. a/A $=$ MR-ad lib vs. MR-res and WM-ad lib; b/B = MR-res vs. MR-ad lib; $\mathrm{c} / \mathrm{C}=\mathrm{MR}$-ad lib vs. WM-ad lib, d/D $=$ MR-res vs. WM-ad lib; e/E $=$ MR-res vs. MR-ad lib and WM-ad lib. MR-res = milk replacer restricted; MR-ad lib = milk replacer ad libitum; WM-ad lib = whole milk ad libitum. 


\section{- MR-res \\ $\longrightarrow$ - MR-ad lib \\ $\longrightarrow$ WM-ad lib}

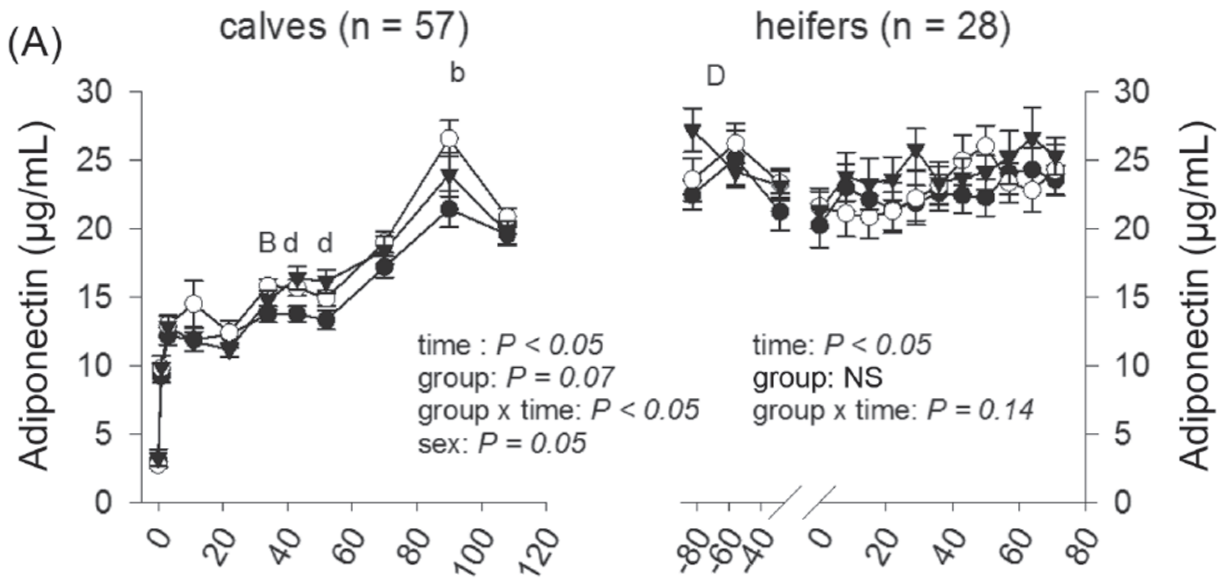

(B)
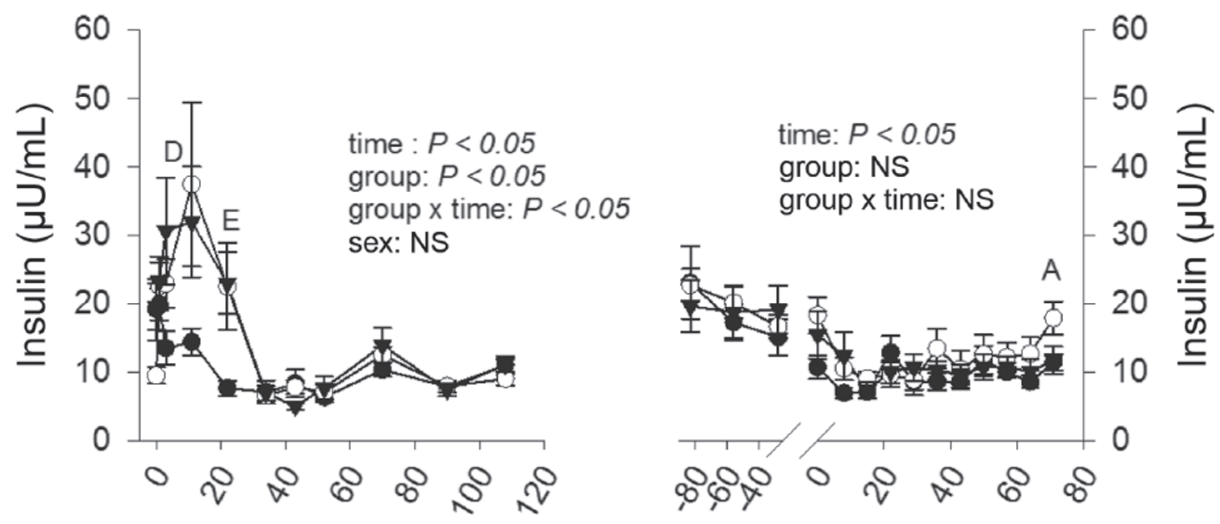

(C)

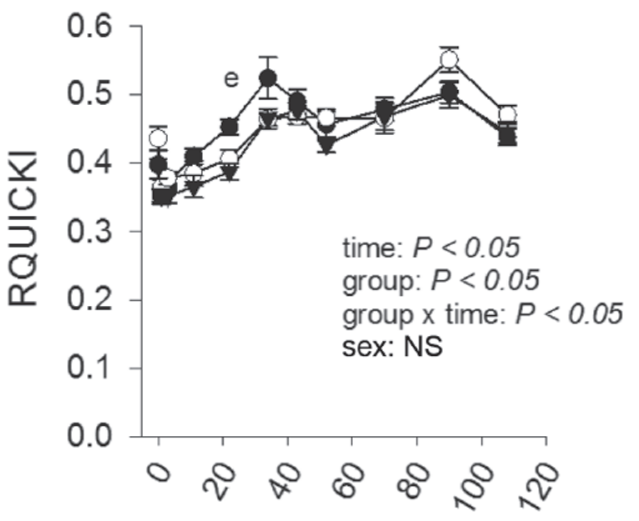

Days of life

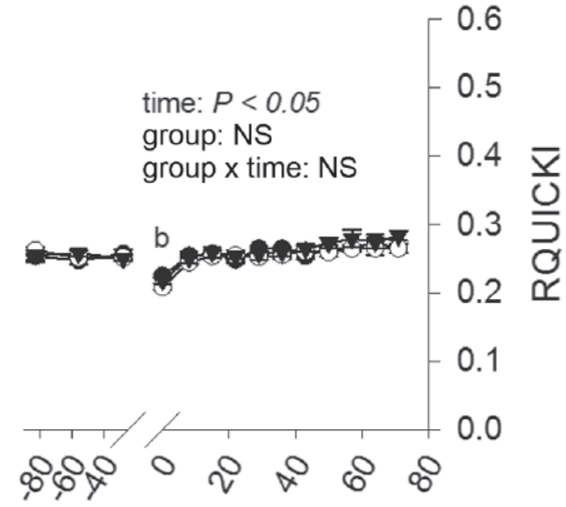

Days around calving

Figure 3. Time-dependent changes (means \pm SEM) of adiponectin (A), insulin (B), and revised quantitative insulin sensitivity check index (RQUICKI; C) from trials 1 (calves) and 2 (heifers). Lowercase letters (b, d, e) indicate differences between groups $(P<0.05)$; uppercase letters $(\mathrm{A}, \mathrm{B}, \mathrm{D}, \mathrm{E})$ indicate trends $(P<0.1)$. a/A = MR-ad lib vs. MR-res and WM-ad lib; b/B = MR-res vs. MR-ad lib; c/C = MR-ad lib vs. WM-ad lib, d/D = MR-res vs. WM-ad lib; e/E = MR-res vs. MR-ad lib and WM-ad lib. The adiponectin concentrations of the MR-res calves were reported previously (Kesser et al., 2015). MR-res $=$ milk replacer restricted; MR-ad lib $=$ milk replacer ad libitum; WM-ad lib $=$ whole milk ad libitum. 
In colostrum, the adiponectin concentrations were greater on $\mathrm{d} 1$ than in milk from d 7 p.p. $(P<0.001$; $76.7 \pm 3.2$ vs. $3.8 \pm 0.3 \mu \mathrm{g} / \mathrm{mL} ; \mathrm{n}=79$; i.e., samples from trial 1 and from 22 additional animals). The correlation between the adiponectin concentration in colostrum and the serum adiponectin concentration of the calves after their first colostrum consumption was $\rho$ $=0.3(P<0.05 ; \mathrm{n}=79 ;$ additional calves $)$. The same correlation was seen with leptin in colostrum and in serum of calves after their first colostrum consumption $(\rho=0.3 ; P<0.05, \mathrm{n}=57$; trial 1$)$.

\section{DISCUSSION}

The different feeding regimens tested in the present study affected the intake of both liquid and solid feeds, as reported in the companion paper (Korst et al., 2017). In brief, the ME from liquid feed during the differential feeding period (P1) was 1.9 fold higher in the ad libitum-fed groups than in the MR-res group. At the same time, the intake of concentrate was low, thus confirming earlier findings that calves eat only little solid feed during the first week of life (Khan et al., 2011). The intake of hay might have been different between the groups during calfhood and might have affected rumen development and performance, as shown by Khan et al. (2012, 2016). Unfortunately, we could not measure the intake of hay that was offered ad libitum; thus, we have to limit our discussion to the effects of concentrate intake. Whereas data about rumen and intestinal development could not be directly assessed, we have some indication from BHB concentrations in serum about rumen development, as discussed below. However, in the lactating heifers, we found no differences in DMI, BW, body condition, milk yields, and energy balance.

\section{Metabolic Traits}

The plasma concentrations of fatty acids, glucose, $\mathrm{BHB}$, and TPP in the dairy calves were consistent with other studies (Hadorn et al., 1997; Hugi and Blum 1997; Hammon et al., 2002). Differences between groups were observed in P1 during the differential feeding; however,

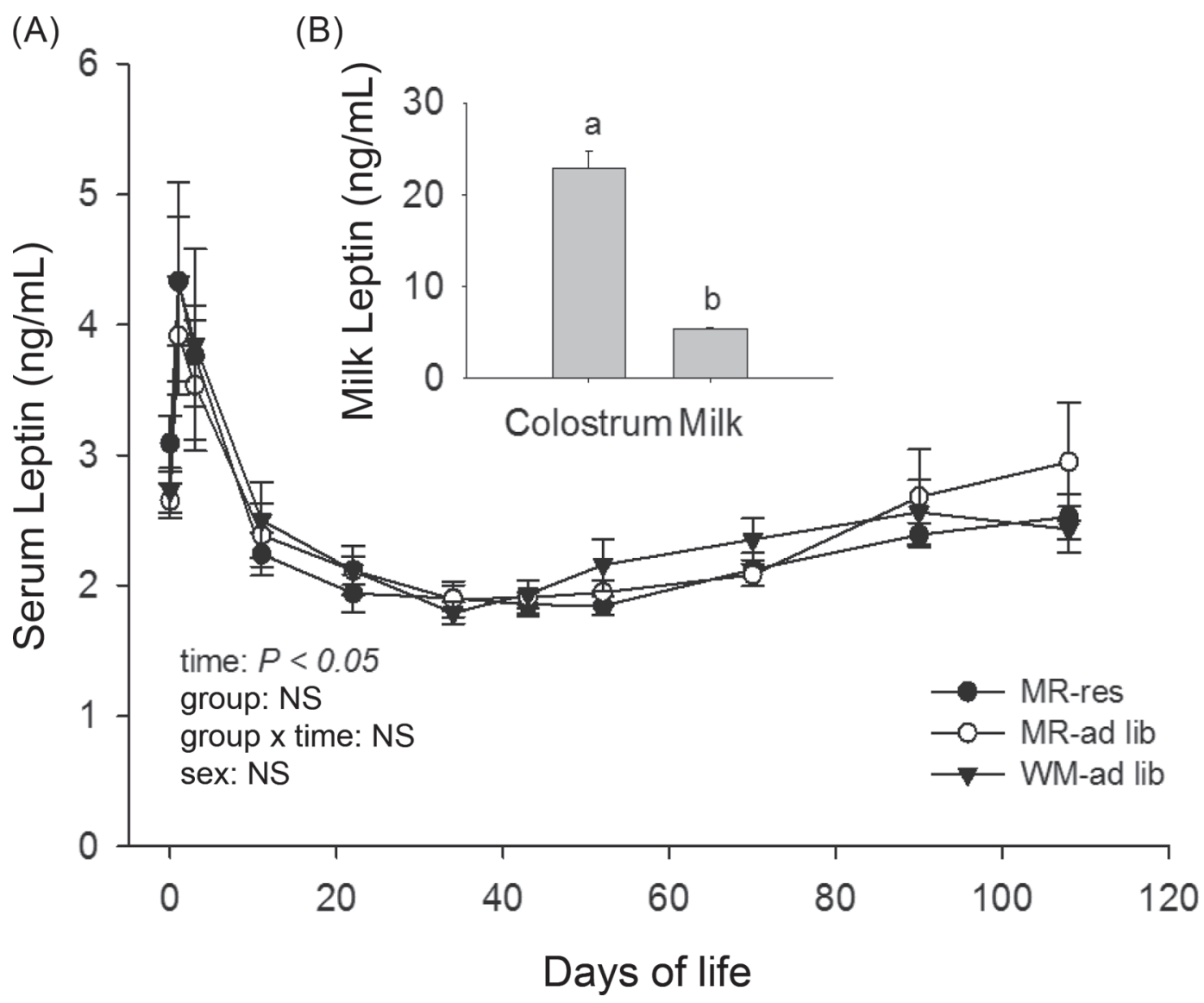

Figure 4. Time-dependent changes (means \pm SEM) of serum leptin in calves $(\mathrm{A} ; \mathrm{n}=57$; trial 1$)$ and leptin concentrations in colostrum and in milk from the corresponding dams $(\mathrm{B})$. Different letters $(\mathrm{a}, \mathrm{b})$ indicate different leptin concentration in colostrum and milk $(P<0.01)$. 
Table 4. The insulin-stimulated blood glucose response (ISBGR, means \pm SEM) in response to an intravenous insulin tolerance test (ITT) performed at different phases $(\mathrm{P})$ of life in male calves reared at different feeding intensities from d 4 to 27 of life ${ }^{1}$

\begin{tabular}{lccc}
\hline & \multicolumn{3}{c}{ ISBGR [\%] } \\
\cline { 2 - 4 } & $\begin{array}{c}\text { MR-res } \\
(\mathrm{n}=9)\end{array}$ & $\begin{array}{c}\text { MR-ad lib } \\
(\mathrm{n}=7)\end{array}$ & $\begin{array}{c}\text { WM-ad lib } \\
(\mathrm{n}=7)\end{array}$ \\
\hline Period & $56.8^{\mathrm{x}} \pm 4.8$ & $52.0 \pm 3.2$ & $52.8 \pm 5.5$ \\
P1 (d 24) & $43.4^{\mathrm{y}} \pm 3.3$ & $48.8 \pm 3.3$ & $45.0 \pm 2.3$ \\
P3 (d 110) & $39.6^{\mathrm{y}} \pm 4.1$ & $43.4 \pm 3.6$ & $43.2 \pm 3.3$ \\
\hline
\end{tabular}

${ }^{x, y}$ Different lowercase letters indicate differences between phases $(P<$ $0.05)$.

${ }^{1} \mathrm{P} 1$ : d 2-27; P2: d 28-69; P3: d 70-110; MR-res $=$ milk replacer restricted; MR-ad lib = milk replacer ad libitum; WM-ad lib = whole milk ad libitum.

after all groups were adapted to the same feeding regimen, these differences disappeared in our study. Similar adaptations were also reported in the literature (Hadorn et al., 1997; Rauprich et al., 2000; Prokop et al., 2015). The greater plasma glucose concentration occasionally observed in the ad libitum-fed dairy calves in our study (Figure 2) might be due to the higher intake of lactose, as observed in veal calves (Hugi et al., 1997). For BHB, differences between the feeding groups were limited to the time after differential feeding. When all calves were on the MR-res regimen (P2), the calves from the preceding WM-ad lib and MR-res groups had greater BHB concentrations than the MR-ad lib group. Increasing BHB concentrations might indicate increased hepatic ketogenesis due to an increased supply or decreased oxidation of fatty acids from mobilization of body fat. Preruminant animals are basically capable of hepatic ketogenesis when fasted, but the increase of BHB in the circulation is more likely related to the beginning ruminal production of ketones (Baldwin et al., 2004). The suitability of serum BHB as an indicator for grain intake and rumen development in calves was recently confirmed (Deelen et al., 2016). Indeed, the intakes of concentrate and the BHB serum concentrations when all calves were fed according to the MR-res protocol until weaning showed the same pattern; the highest values in both variables were observed in the WM-ad lib and MR-res groups, whereas the MR-ad lib group ate about $200 \mathrm{~g} / \mathrm{d}$ less concentrate (Korst et al., 2017) and had around $80 \%$ of the BHB concentrations. We expected the MR-res group to have the fastest BHB increase and to differ from both ad libitum groups, as early restriction for liquid feed would stimulate the intake of concentrate. In contrast to this expectation, the BHB blood concentrations in calves from the WM-ad lib feeding group were not different from the MR-res group, but both groups had higher values than the MR-ad lib group. This finding might point to beneficial 


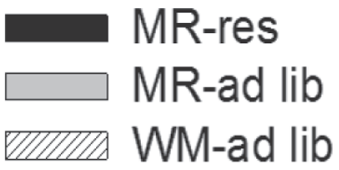

(A)

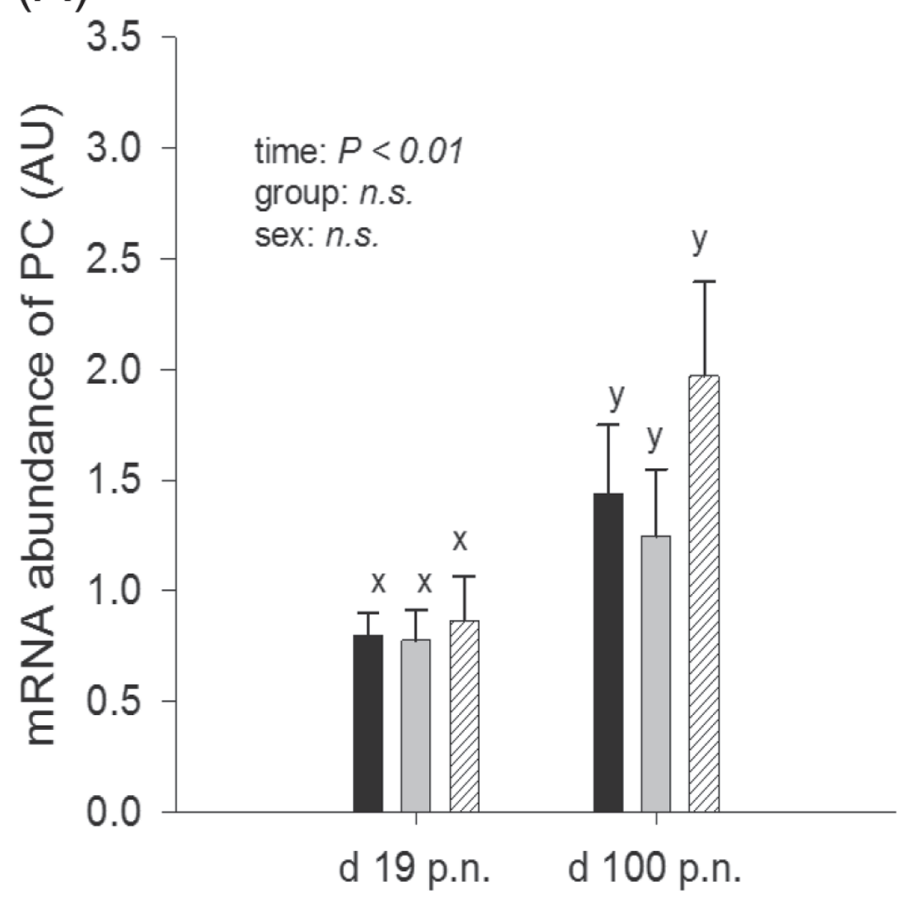

(B)

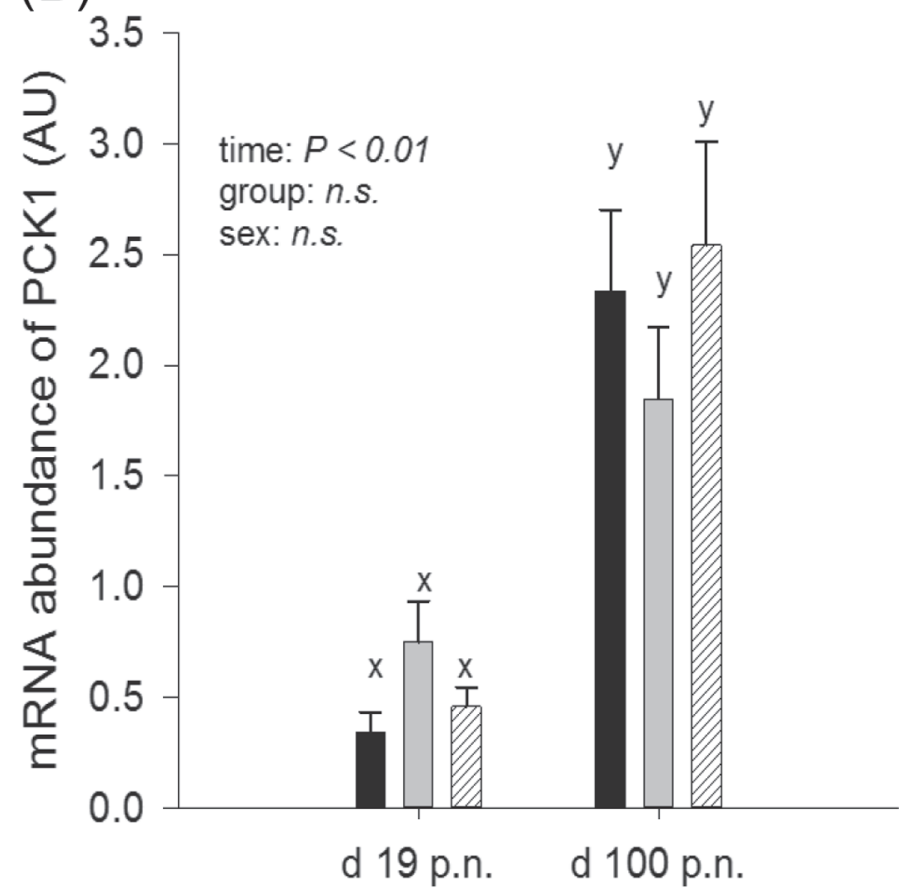

Figure 5. mRNA abundance of pyruvate carboxylase (PC; A) and phosphoenolpyruvate carboxykinase (PCK1; B) on d 19 and 100 postnatal (p.n.). Different letters $(\mathrm{x}, \mathrm{y})$ indicate differences between sampling time points $(P<0.01)$.

effects of WM feeding on rumen development by milkborne stimuli. Rumen development could be directly or indirectly affected through promoting a rumen microbiome, which in turn accelerates rumen development and might also concern the entire intestinal tract (Steele et al., 2016).

In heifers, the metabolite concentrations in our study were typical for the transition period, as observed earlier (Wathes et al., 2007; Weber et al., 2013). We found no group differences in the plasma concentrations of fatty acids or glucose. The BHB concentrations tended to be lower in the WM-ad lib group than in the MR-ad lib group in late pregnancy. In contrast to the findings during calfhood, when BHB in blood likely reflects rumen development, $\mathrm{BHB}$ concentrations in blood of late pregnant and of lactating cows indicate mainly increased ketogenesis. The observation of sporadically lower BHB concentrations in heifers reared on the WMad lib regimen might point to a greater capacity for the complete oxidation of fatty acids in these animals; however, the values reached in all heifers were still in a normal range and the difference was transient only.
Before calving, urea was lower in the WM-ad lib group than in the MR-res and MR-ad lib groups. It is unlikely that these differences resulted from feed composition and feed intake, as all heifers received the same ration and the DMI was not different (although intake could be recorded only postpartum). The highest concentrations were observed in the MR-ad lib group and might point toward a less efficient ruminal microbiome; however, all values were well within the reference values suggested for late pregnant and Holstein cows (Brscic et al., 2015) and the difference between the groups disappeared after calving. Nevertheless the data may provide some support for a more efficient $\mathrm{N}$ utilization in WM-ad lib-reared heifers. Taking the differences in blood urea a.p. together with the findings from BHB during calfhood, we speculated that WM feeding might be superior to both MR feeding regimens in terms of nutrient utilization.

When taking the results from the metabolites together, they provide some support, however minor, for our hypothesis that ab libitum feeding of WM will be more beneficial than feeding MR ad libitum. In general, 
the greater nutrient supply by ad libitum feeding during the first weeks of life is now generally accepted as being beneficial for long-term growth and productivity (Khan et al., 2011).

\section{Hormones}

The serum leptin concentrations in neonatal calves slightly increased with the first intake of colostrum in our study. The colostral leptin concentrations decreased from d 1 to 3 by a factor of 4 . Woliński et al. (2014) reported a 3 -fold increase of the leptin concentrations in plasma of piglets after the first feeding of colostrum. In the corresponding samples of sow colostrum and milk, the leptin concentrations increased from d 1 to 3 p.p. and then decreased to d 7 p.p. (Woliński et al., 2014). Casabiell et al. (1997) showed that leptin is transferred from the maternal circulation into the milk and through the stomach of neonatal rats into the bloodstream without a loss of biological activity. Leptin from colostrum and milk was suggested to be important for the development of the small intestine, as the maturation of the small intestine in piglets was slowed down when only formula was fed (Woliński et al., 2003). However, the leptin concentrations in colostrum and in plasma of neonatal piglets were not correlated (Woliński et al., 2014), whereas we observed a weak correlation $(\rho=0.3$; $P<0.05 ; \mathrm{n}=57)$ in dairy calves. The role of colostral leptin seems less clear, as the increase of serum leptin observed in the present study upon colostrum intake was not observed in 2 other studies (Blum et al., 2005; Schäff et al., 2014); however, this might have been due to the relatively small animal numbers in these studies, which did not allow for picking up the small and transient increase we were able to show herein. When comparing calves receiving only MR with colostrum-fed calves, the leptin concentrations were lower in MR-fed calves (Schäff et al., 2014). However, it is improbable that individual adipokines, such as leptin or adiponectin, out of a plethora of other bioactive components contained in colostrum would alone mediate the beneficial (not immune globulin-related) effects commonly associated with colostrum intake.

In contrast to our previous study involving only 10 males and 10 female calves (Kesser et al., 2015), in which no sex difference was established for adiponectin during the first $110 \mathrm{~d}$ of life, the female calves in the present study $(\mathrm{n}=29)$ had greater adiponectin concentrations than the males $(\mathrm{n}=28 ; P=0.05)$. In human babies, data concerning sex differences were contradictory (Sivan et al., 2003; Kamoda et al., 2004; Erhardt et al., 2014).

The trend to lower adiponectin serum concentrations in the MR-res-fed calves compared with the MR-ad lib calves indicated a reduced insulin sensitivity in the MR-res group; however, the results of the GTT (as discussed below) contradict this finding. The nadir of adiponectin around parturition in the young heifers is in line with other studies (Giesy et al., 2012; Mielenz et al., 2013; Singh et al., 2014), and may be interpreted as support for the nutrient supply toward the mammary gland by decreasing the insulin sensitizing, gluconeogenesis, and lipolysis-inhibiting effects (Yamauchi et al., 2002; Kadowaki et al., 2006; Singh et al., 2014). In addition, the decreased adiponectin concentrations around calving might resulted from the increased secretion of blood adiponectin into colostrum (Singh et al., 2014). However, only a weak positive correlation $(\rho=$ $0.3 ; P<0.05 ; \mathrm{n}=79$ ) was seen between the plasma adiponectin concentrations and the colostrum adiponectin concentrations.

In intensively fed calves the insulin concentration increases (Hadorn et al., 1997; Hammon and Blum, 1998; Kühne et al., 2000), but is commonly not sustained when the animals are moved to a less-intensive feeding regimen. The increased insulin concentration in the ad libitum groups from the present study was probably due to the greater amounts of ingested energy compared with the MR-res group, as reported in veal calves (Hugi et al., 1997, Maccari et al., 2015). Decreased insulin concentrations around parturition, as observed in the heifers from our study and reported previously (Swali and Wathes, 2006; De Koster and Opsomer, 2013), point to reduced lipogenesis and protein synthesis and enhanced lipolysis and, thus, support the flux of glucose and AA to the mammary gland (De Koster and Opsomer, 2013). However, insulin concentrations were not affected by rearing conditions during the first weeks of life, which is in contrast to studies in rats, where intensive feeding in early life stimulated the development of the pancreatic cells and lead to higher insulin concentrations in later life (Srinivasan et al., 2003). In intensively fed male German Holstein calves, an increase in the number of the islets of Langerhans was observed after 8 mo of life (Prokop et al., 2015). In early life, the pancreatic cells as well as the adipose tissue continue to develop and to establish the total number of cells (Kaung, 1994; Spalding et al., 2008); therefore, these tissues serve as potential targets of metabolic programming (Mostyn and Symonds, 2009; Duque-Guimarães and Ozanne, 2013; Barella et al., 2014).

Greater milk yields after an intensive feeding regimen in the preweaning period were reported in several studies (Bar-Peled et al., 1997; Moallem et al., 2010; Soberon et al., 2012). In our study, the greater milk yield of the ad libitum groups was not significant as shown in our companion paper (Korst et al., 2017). Reasons for increased milk yields after intensive feed- 
ing regimens in the preweaning period comprise the increased mammary parenchymal mass, parenchymal DNA and RNA (Brown et al., 2005). A positive influence of intensive feeding regimen in the preweaning period on the mammary gland parenchyma was shown previously (Brown et al., 2005; Meyer et al., 2006; Geiger et al., 2016). Tucker (1981) stated that one of the primary determinants for milk production is the number of cells available for synthesis of milk. Before puberty, the mammary gland grows in an allometric fashion (Esselburn et al., 2015); therefore, the mammary gland might be more sensitive to external stimuli compared with the remaining tissues. The influence of different feeding regimens before puberty might have long-term programming effects on the development of the mammary gland and, therefore, on the lifetime milk yield production of dairy cows.

\section{Variables Describing Insulin Sensitivity}

In the dairy calves from the present study, the GTT variables suggested a higher insulin sensitivity in the MR-res group compared with the ad libitum groups in P1. The trend for higher RQUICKI values, as surrogate indicator for insulin sensitivity, in the MR-res group compared with the WM-ad lib group supported the latter result. The accordance between GTT variables and RQUICKI values in dairy calves was confirmed earlier (Bossaert et al., 2009). The ISBGR from the ITT did not differ between groups and in the MR-res group a significant decrease was only observed from P1 to P3, indicating decreased insulin responsiveness (Ohtsuka et al., 2001). In contrast, the trend for lower plasma adiponectin concentrations in calves of the MRres group suggests lower insulin sensitivity in the MRres group than in the ad libitum groups. Some reports confirm that insulin sensitivity is decreased by more intensive feeding levels (Bach et al., 2013; Yunta et al., 2015), whereas others could not confirm such effects (MacPherson et al., 2016). The divergent results from these studies, including ours, might be explained by differences in the age when the feeding regimens were started as well as the setting of the GTT performed (i.e., the fasting time before starting the GTT and also the age when the GTT were performed). Additional factors likely influencing the response are the amount and composition of the MR used and the feeding frequency (usually 2 times daily versus the free access in our study, resulting in average meal sizes of about 1.3 $\mathrm{kg})$.

In the heifers, no group differences in RQUICKI values were observed. However, a slight decrease around parturition might indicate a decreased insulin sensitiv- ity and support previous findings (Holtenius and Holtenius, 2007; Singh et al., 2014). In dairy cows, Singh et al. (2014) demonstrated a positive correlation between plasma adiponectin concentrations and RQUICKI values; this was not confirmed in our study. However, in dairy calves, we found a negative correlation during P0, $\mathrm{P} 1$, and P2. In contrast to tissues of nonruminant animals, the tissues of dairy cows seem to be less sensitive to insulin (Brockman and Laarveld, 1986). Adiponectin is known for its insulin sensitizing effects (Berg et al., 2002). However, the change from a negative correlation between adiponectin and RQUICKI values in calves to a positive correlation in dairy cows (Singh et al., 2014) probably occurs after weaning. The adiponectin system in preruminant calves might still be developing and not yet mature; moreover, the adiponectin system might have different functions than increasing insulin sensitivity at that age. Therefore, measuring adiponectin in calves seems inappropriate to infer information about insulin sensitivity.

Taken together, even though high feeding planes were shown to alter insulin sensitivity and glucose metabolism in some studies, including ours, if tested in later life these effects seem transient only and there is no evidence for sustained effects. Our results about the various hormones do not supporting our initial hypotheses that ad libitum feeding, in particular of whole milk, will elicit sustained changes of metabolic hormones that will continue until lactation and promote milk production. Bearing in mind that the small sample size available for trial 2 may have impeded the detection of sustained differences, as well as the transient nature of the hormonal and metabolic changes induced by the feeding during the first weeks of life, ad libitum feeding might nevertheless have affected the development of target tissues, in particular the development of gastrointestinal tract and the mammary gland.

\section{mRNA Abundance of Enzymes}

The increase of the mRNA abundance of pyruvate carboxylase and phosphoenolpyruvate carboxykinase from the first to the second biopsy observed herein indicates an increase of gluconeogenesis that is probably related to the switch from the preruminant to the ruminant stage. The main trigger of this switch is the change of substrates from lactose to short-chain fatty acids, in particular propionate (Greenfield et al., 2000; Aschenbach et al., 2010; Steinhoff-Wagner et al., 2011). As observed in our study and in earlier studies (Scheuer et al., 2006; Steinhoff-Wagner et al., 2011), different feeding regimens in the preweaning period had no influence on the mRNA abundance of pyruvate 
carboxylase and phosphoenolpyruvate carboxykinase, indicating that the endogenous glucose production was not affected.

\section{CONCLUSIONS}

In times of differential milk feeding (d 4-27 p.n.) differences in the circulating concentrations of some metabolites and hormones were observed between groups. However, in contrast to our working hypothesis, these differences were not sustained when all calves received the same feed later on. Moreover, when considering the animals as pregnant and then lactating heifers, their endocrine and metabolic patterns were not different. Therefore, no programming effects on metabolism and its endocrine regulators could be identified. Programming effects on gastrointestinal function or the cellular development of the mammary gland may not be ruled out, but should be addressed in further studies involving more animals.

\section{ACKNOWLEDGMENTS}

We thank B. Mielenz (University of Bonn/FBN Dummerstorf, Germany) and Inga Hofs and Isabella Israel (both University of Bonn) for their excellent technical assistance. Many thanks also to the technical staff of the Educational and Research Centre for Animal Husbandry, Hofgut Neumuehle, Muenchweiler a.d. Alsenz, Germany. This research was partly conducted by members of the Center of Integrated Dairy Research (CIDRe), University of Bonn (Bonn, Germany).

\section{REFERENCES}

Aschenbach, J. R., N. B. Kristensen, S. S. Donkin, H. M. Hammon, and G. B. Penner. 2010. Gluconeogenesis in dairy cows: the secret of making sweet milk from sour dough. IUBMB Life 62:869-877. https://doi.org/10.1002/iub.400.

Bach, A. 2012. Ruminant nutrition symposium: Optimizing performance of the offspring: Nourishing and managing the dam and postnatal calf for optimal lactation, reproduction, and immunity, J. Anim. Sci. 90:1835-1845. https://doi.org/10.2527/jas.20114516.

Bach, A., and J. Ahedo. 2008. Record keeping and economics of dairy heifers: Dairy heifer management. Vet. Clin. North Am. Food Anim. Pract. 24:117-138. https://doi.org/10.1016/j.cvfa.2007.10.001.

Bach, A., L. Domingo, C. Montoro, and M. Terré. 2013. Short communication: Insulin responsiveness is affected by the level of milk replacer offered to young calves. J. Dairy Sci. 96:4634-4637. https:// doi.org/10.3168/jds.2012-6196.

Baldwin, R. L., K. R. McLeod, J. K. Klotz, and R. N. Heitmann. 2004. Rumen development, intestinal growth and hepatic metabolism in the pre- and postweaning ruminant. J. Dairy Sci. 87:E55-E65.

Bar-Peled, U., B. Robinzon, E. Maltz, H. Tagari, Y. Folman, I. Bruckental, H. Voet, H. Gacitua, and A. R. Lehrer. 1997. Increased weight gain and effects on production parameters of Holstein heifer calves that were allowed to suckle from birth to six weeks of age. J. Dairy Sci. 80:2523-2528. https://doi.org/10.3168/jds.S00220302(97)76205-2.
Barella, L. F., J. C. de Oliveira, and M. Paulo Cezar de Freitas. 2014. Pancreatic islets and their roles in metabolic programming. Nutrition 30:373-379. https://doi.org/10.1016/j.nut.2013.07.012.

Bell, A. W., and D. E. Bauman. 1997. Adaptations of glucose metabolism during pregnancy and lactation. J. Mammary Gland Biol. Neoplasia 2:265-278. https://doi.org/10.1023/A:1026336505343.

Berg, A. H., T. P. Combs, and P. E. Scherer. 2002. ACRP30/adiponectin: An adipokine regulating glucose and lipid metabolism. Trends Endocrinol. Metab. 13:84-89.

Blum, J. W., Y. Zbinden, H. M. Hammon, and Y. Chilliard. 2005. Plasma leptin status in young calves: Effects of pre-term birth, age, glucocorticoid status, suckling, and feeding with an automatic feeder or by bucket. Domest. Anim. Endocrinol. 28:119-133. https://doi.org/10.1016/j.domaniend.2004.06.011.

Bossaert, P., J. L. M. R. Leroy, S. de Campeneere, S. de Vliegher, and G. Opsomer. 2009. Differences in the glucose-induced insulin response and the peripheral insulin responsiveness between neonatal calves of the Belgian Blue, Holstein-Friesian, and East Flemish breeds. J. Dairy Sci. 92:4404-4411. https://doi.org/10.3168/ jds.2009-2218.

Brockman, R. P., and B. Laarveld. 1986. Hormonal regulation of metabolism in ruminants; A review. Livest. Prod. Sci. 14:313-334. https://doi.org/10.1016/0301-6226.

Brown, E. G., M. J. VandeHaar, K. M. Daniels, J. S. Liesman, L. T. Chapin, J. W. Forrest, R. M. Akers, R. E. Pearson, and M. W. Nielsen. 2005. Effect of increasing energy and protein intake on mammary development in heifer calves. J. Dairy Sci. 88:595-603. https://doi.org/10.3168/jds.S0022-0302(05)72723-5.

Brscic, M., G. Cozzi, I. Lora, A. L. Stefani, B. Contiero, L. Ravarotto, and F. Gottardo. 2015. Short communication: Reference limits for blood analytes in Holstein late-pregnant heifers and dry cows: Effects of parity, days relative to calving, and season. J. Dairy Sci. 98:7886-7892. https://doi.org/10.3168/jds.2015-9345.

Casabiell, X., V. Piñeiro, M. A. Tomé, R. Peinó, C. Dieguez, and F. F. Casanueva. 1997. Presence of leptin in colostrum and/or breast milk from lactating mothers: a potential role in the regulation of neonatal food intake. J. Clin. Endocrinol. Metab. 82:4270-4273. https://doi.org/10.1210/jcem.82.12.4590.

De Koster, J. D., and G. Opsomer. 2013. Insulin resistance in dairy cows. Vet. Clin. North Am. Food Anim. Pract. 29:299-322.

Deelen, S. M., K. E. Leslie, M. A. Steele, E. Eckert, H. E. Brown, and T. J. DeVries. 2016. Validation of a calf-side $\beta$-hydroxybutyrate test and its utility for estimation of starter intake in dairy calves around weaning. J. Dairy Sci. https://doi.org/10.3168/jds.201611097. In press.

Duque-Guimarães, D. E., and S. E. Ozanne. 2013. Nutritional programming of insulin resistance: causes and consequences. Trends Endocrinol. Metab. 24:525-535. https://doi.org/10.1016/j. tem.2013.05.006.

Erhardt, E., R. Foraita, I. Pigeot, G. Barba, T. Veidebaum, N. Michels, G. Eiben, W. Ahrens, L. A. Moreno, E. Kovács, and D. Molnár. 2014. Reference values for leptin and adiponectin in children below the age of 10 based on the IDEFICS cohort. Int. J. Obes. (Lond.) 38(Suppl. 2):32-38.

Esselburn, K. M., T. M. Hill, H. G. Bateman II, F. L. Fluharty, S. J. Moeller, K. M. O'Diam, and K. M. Daniels. 2015. Examination of weekly mammary parenchymal area by ultrasound, mammary mass, and composition in Holstein heifers reared on 1 of 3 diets from birth to 2 months of age. J. Dairy Sci. 98:5280-5293. https:// doi.org/10.3168/jds.2014-9061.

Geiger, A. J., C. Parsons, R. E. James, and R. M. Akers. 2016. Growth, intake, and health of Holstein heifer calves fed an enhanced preweaning diet with or without postweaning exogenous estrogen. J. Dairy Sci. https://doi.org/10.3168/jds.2015-10405. In press.

Giesy, S. L., B. Yoon, W. B. Currie, J. W. Kim, and Y. R. Boisclair. 2012. Adiponectin deficit during the precarious glucose economy of early lactation in dairy cows. Endocrinology 153:5834-5844. https://doi.org/10.1210/en.2012-1765.

Greenfield, R. B., M. J. Cecava, and S. S. Donkin. 2000. Changes in mRNA expression for gluconeogenic enzymes in liver of dairy cat- 
tle during the transition to lactation. J. Dairy Sci. 83:1228-1236. https://doi.org/10.3168/jds.S0022-0302(00)74989-7.

Hadorn, U., H. Hammon, R. M. Bruckmaier, and J. W. Blum. 1997. Delaying colostrum intake by one day has important effects on metabolic traits and on gastrointestinal and metabolic hormones in neonatal calves. J. Nutr. 127:2011-2023.

Hammon, H., and J. W. Blum. 1998. Endocrine and metabolic changes in neonatal calves in response to growth hormone and long-R3insulin-like growth factor-I administration. Biol. Neonate 73:121128.

Hammon, H. M., G. Schiessler, A. Nussbaum, and J. W. Blum. 2002. Feed intake patterns, growth performance, and metabolic and endocrine traits in calves fed unlimited amounts of colostrum and milk by automate, starting in the neonatal period. J. Dairy Sci. 85:3352-3362.

Hammon, H. M., G. Stürmer, F. Schneider, A. Tuchscher, H. Blum, T. Engelhard, A. Genzel, R. Staufenbiel, and W. Kanitz. 2009. Performance and metabolic and endocrine changes with emphasis on glucose metabolism in high-yielding dairy cows with high and low fat content in liver after calving. J. Dairy Sci. 92:1554-1566.

Heinrichs, A. J., and B. S. Heinrichs. 2011. A prospective study of calf factors affecting first-lactation and lifetime milk production and age of cows when removed from the herd. J. Dairy Sci. 94:336-341. https://doi.org/10.3168/jds.2010-3170.

Holtenius, P., and K. Holtenius. 2007. A model to estimate insulin sensitivity in dairy cows. Acta Vet. Scand. 49:29-31. https://doi. org/10.1186/1751-0147-49-29.

Hosseini, A., H. Sauerwein, and M. Mielenz. 2010. Putative reference genes for gene expression studies in propionate and $\beta$-hydroxybutyrate treated bovine adipose tissue explants. J. Anim. Physiol. Anim. Nutr. (Berl.) 94:e178-184. /https://doi. org/10.1111/j.1439-0396.2010.01002.x.

Hugi, D., and J. W. Blum. 1997. Changes of blood metabolites and hormones in breeding calves associated with weaning. Zentralbl. Veterinarmed. A 44:99-108.

Hugi, D., S. H. Gut, and J. W. Blum. 1997. Blood metabolites and hormones - especially glucose and insulin - in veal calves: Effects of age and nutrition. Zentralbl. Veterinarmed. A 44:407-416.

Kadowaki, T., T. Yamauchi, N. Kubota, K. Hara, K. Ueki, and K. Tobe. 2006. Adiponectin and adiponectin receptors in insulin resistance, diabetes, and the metabolic syndrome. J. Clin. Invest. 116:1784-1792. https://doi.org/10.1172/JCI29126.

Kamoda, T., H. Saitoh, M. Saito, M. Sugiura, and A. Matsui. 2004. Serum adiponectin concentrations in newborn infants in early postnatal life. Pediatr. Res. 56:690-693. https://doi.org/10.1203/01. PDR.0000142711.24999.8A

Kaung, H. L. 1994. Growth dynamics of pancreatic islet cell populations during fetal and neonatal development of the rat. Dev. Dyn. 200:163-175. https://doi.org/10.1002/aja.1002000208.

Kesser, J., M. Hill, J. F. L. Heinz, C. Koch, J. Rehage, J. SteinhoffWagner, H. M. Hammon, B. Mielenz, H. Sauerwein, and H. Sadri. 2015. The rapid increase of circulating adiponectin in neonatal calves depends on colostrum intake. J. Dairy Sci. 98:7044-7051. https://doi.org/10.3168/jds.2015-9726.

Khan, M. A., A. Bach, D. M. Weary, and M. A. von Keyserlingk. 2016. Transitioning from milk to solid feed in dairy heifers. J. Dairy Sci. 99:885-902. https://doi.org/10.3168/jds.2015-9975.

Khan, M. A., D. M. Weary, D. M. Veira, and M. A. von Keyserlingk. 2012. Postweaning performance of heifers fed starter with and without hay during the milk-feeding period. J. Dairy Sci. 95:39703976. https://doi.org/10.3168/jds.2011-5027.

Khan, M. A., D. M. Weary, and M. A. von Keyserlingk. 2011. Effects of milk ration on solid feed intake, weaning, and performance in dairy heifers. J. Dairy Sci. 94:1071-1081. https://doi.org/10.3168/ jds.2010-3733.

Korst, M., C. Koch, J. Kesser, U. Müller, F. J. Romberg, J. Rehage, K. Eder, and H. Sauerwein. 2017. Different feeding intensities during the first 4 weeks of rearing in dairy calves: Part 1: Effects on performance and production from birth over the first lactation. J. Dairy Sci. 100:3096-3108. http://dx.doi.org/10.3168/jds.201611594.
Kühne, S., H. M. Hammon, R. M. Bruckmaier, C. Morel, Y. Zbinden, and J. W. Blum. 2000. Growth performance, metabolic and endocrine traits, and absorptive capacity in neonatal calves fed either colostrum or milk replacer at two levels. J. Anim. Sci. 78:609-620.

Lucas, A. 1991. Programming by early nutrition in man. Ciba Found. Symp. 156:38-50.

Maccari, P., S. Wiedemann, H. J. Kunz, M. Piechotta, P. Sanftleben, and M. Kaske. 2015. Effects of two different rearing protocols for Holstein bull calves in the first 3 weeks of life on health status, metabolism and subsequent performance. J. Anim. Physiol. Anim. Nutr. (Berl.) 99:737-746. https://doi.org/10.1111/jpn.12241.

MacPherson, J. A. R., H. Berends, L. N. Leal, J. P. Cant, J. MartínTereso, and M. A. Steele. 2016. Effect of plane of milk replacer intake and age on glucose and insulin kinetics and abomasal emptying in female Holstein Friesian dairy calves fed twice daily. J. Dairy Sci. 99:8007-8017. https://doi.org/10.3168/jds.2015-10826.

Martin-Gronert, M. S., and S. E. Ozanne. 2012. Metabolic programming of insulin action and secretion. Diabetes Obes. Metab. 14:29 39. /https://doi.org/10.1111/j.1463-1326.2012.01653.x.

Meyer, M. J., A. V. Capuco, D. A. Ross, L. M. Lintault, and M. E. Van Amburgh. 2006. Developmental and nutritional regulation of the prepubertal bovine mammary gland: II. Epithelial cell proliferation, parenchymal accretion rate, and allometric growth. J. Dairy Sci. 89:4298-4304.

Mielenz, M., B. Kuhla, and H. M. Hammon. 2013. Abundance of adiponectin system and G-protein coupled receptor GPR109A mRNA in adipose tissue and liver of F2 offspring cows of Charolais $\times$ German Holstein crosses that differ in body fat accumulation. J. Dairy Sci. 96:278-289. https://doi.org/10.3168/jds.2012-5816.

Moallem, U., D. Werner, H. Lehrer, M. Zachut, L. Livshitz, S. Yakoby, and A. Shamay. 2010. Long-term effects of ad libitum whole milk prior to weaning and prepubertal protein supplementation on skeletal growth rate and first-lactation milk production. J. Dairy Sci 93:2639-2650. https://doi.org/10.3168/jds.2009-3007.

Mostyn, A., and M. E. Symonds. 2009. Early programming of adipose tissue function: A large-animal perspective. Proc. Nutr. Soc. 68:393-400. https://doi.org/10.1017/S002966510999022X.

Ohtsuka, H., M. Koiwa, A. Hatsugaya, K. Kudo, F. Hodhi, N. Itoh, H. Yokota, H. Okada, and S. Kawamura. 2001. Relationship between serum tnf activity and insulin resistance in dairy cows affected with naturally occurring fatty liver. J. Vet. Med. Sci. 63:10211025. https://doi.org/10.1292/jvms.63.1021.

Oikawa, S., and G. R. Oetzel. 2006. Decreased insulin response in dairy cows following a four-day fast to induce hepatic lipidosis. J. Dairy Sci. 89:2999-3005. https://doi.org/10.3168/jds.S00220302(06) 72572-3.

Perseghin, G., A. Caumo, M. Caloni, G. Testolin, and L. Luzi. 2001. Incorporation of the fasting plasma FFA concentration into QUICKI improves its association with insulin sensitivity in nonobese individuals. J. Clin. Endocrinol. Metab. 86:4776-4781. https://doi. org/10.1210/jcem.86.10.7902.

Prokop, L., M. Kaske, P. Maccari, R. Lucius, H.-J. Kunz, and S. Wiedemann. 2015. Intensive rearing of male calves during the first three weeks of life has long-term effects on number of islets of Langerhans and insulin stained area in the pancreas. J. Anim. Sci. 93:988-998. https://doi.org/10.2527/jas.2014-8144.

Rauprich, A. B., H. M. Hammon, and J. W. Blum. 2000. Effects of feeding colostrum and a formula with nutrient contents as colostrum on metabolic and endocrine traits in neonatal calves. Biol. Neonate 78:53-64. https://doi.org/14247.

Saremi, B., A. Al-Dawood, S. Winand, U. Müller, J. Pappritz, D von Soosten, J. Rehage, S. Dänicke, S. Häussler, M. Mielenz, and H. Sauerwein. 2012. Bovine haptoglobin as an adipokine: Serum concentrations and tissue expression in dairy cows receiving a conjugated linoleic acids supplement throughout lactation. Vet. Immunol. Immunopathol. 146:201-211. https://doi.org/10.1016/j. vetimm.2012.03.011

Sauerwein, H., U. Heintges, M. Hennies, T. Selhorst, and A. Daxenberger. 2004. Growth hormone induced alterations of leptin serum concentrations in dairy cows as measured by a novel enzyme immu- 
noassay. Livest. Prod. Sci. 87:189-195. https://doi.org/10.1016/j. livprodsci.2003.08.001.

Schäff, C. T., D. Rohrbeck, J. Steinhoff-Wagner, E. Kanitz, H. Sauerwein, R. M. Bruckmaier, and H. M. Hammon. 2014. Effects of colostrum versus formula feeding on hepatic glucocorticoid and $\alpha_{1^{-}}$ and $\beta_{2}$-adrenergic receptors in neonatal calves and their effect on glucose and lipid metabolism. J. Dairy Sci. 97:6344-6357. https:// doi.org/10.3168/jds.2014-8359.

Scheuer, B. H., Y. Zbinden, P. Schneiter, L. Tappy, J. W. Blum, and H. M. Hammon. 2006. Effects of colostrum feeding and glucocorticoid administration on insulin-dependent glucose metabolism in neonatal calves. Domest. Anim. Endocrinol. 31:227-245. https:// doi.org/10.1016/j.domaniend.2005.11.004.

Schulz, K., J. Frahm, S. Kersten, U. Meyer, J. Rehage, M. Piechotta, M. Meyerholz, G. Breves, D. Reiche, H. Sauerwein, and S. Dänicke. 2015. Effects of inhibiting dipeptidyl peptidase-4 (DPP4) in cows with subclinical ketosis. PLoS One 10:e0136078 https://doi. org/10.1371/journal.pone.0136078.

Shamay, A., D. Werner, U. Moallem, H. Barash, and I. Bruckental. 2005. Effect of nursing management and skeletal size at weaning on puberty, skeletal growth rate, and milk production during first lactation of dairy heifers. J. Dairy Sci. 88:1460-1469. https://doi. org/10.3168/jds.S0022-0302(05)72814-9.

Singh, S. P., S. Häussler, J. J. Gross, F. J. Schwarz, R. M. Bruckmaier, and H. Sauerwein. 2014. Short communication: Circulating and milk adiponectin change differently during energy deficiency at different stages of lactation in dairy cows. J. Dairy Sci. 97:15351542. https://doi.org/10.3168/jds.2013-7598.

Sivan, E., S. Mazaki-Tovi, C. Pariente, Y. Efraty, E. Schiff, R. Hemi, and H. Kanety. 2003. Adiponectin in human cord blood: Relation to fetal birth weight and gender. J. Clin. Endocrinol. Metab. 88:5656-5660.

Soberon, F., E. Raffrenato, R. W. Everett, and M. E. van Amburgh. 2012. Preweaning milk replacer intake and effects on long-term productivity of dairy calves. J. Dairy Sci. 95:783-793. https://doi. org/10.3168/jds.2011-4391.

Soberon, F., and M. E. van Amburgh. 2013. Lactation biology symposium: The effect of nutrient intake from milk or milk replacer of preweaned dairy calves on lactation milk yield as adults: A metaanalysis of current data. J. Anim. Sci. 91:706-712. https://doi. org/10.2527/jas.2012-5834.

Spalding, K. L., E. Arner, P. O. Westermark, S. Bernard, B. A. Buchholz, O. Bergmann, L. Blomqvist, J. Hoffstedt, E. Näslund, T. Britton, H. Concha, M. Hassan, M. Rydén, J. Frisén, and P. Arner. 2008. Dynamics of fat cell turnover in humans. Nature 453:783787. https://doi.org/10.1038/nature06902.

Srinivasan, M., S. G. Laychok, D. J. Hill, and M. S. Patel. 2003. Neonatal nutrition: Metabolic programming of pancreatic islets and obesity. Exp. Biol. Med. (Maywood) 228:15-23.
Steele, M. A., G. B. Penner, F. Chaucheyras-Durand, and L. le Guan. 2016. Development and physiology of the rumen and the lower gut: Targets for improving gut health. J. Dairy Sci. 99:4955-4966. https://doi.org/10.3168/jds.2015-10351.

Steinhoff-Wagner, J., S. Görs, P. Junghans, R. M. Bruckmaier, E. Kanitz, C. C. Metges, and H. M. Hammon. 2011. Intestinal glucose absorption but not endogenous glucose production differs between colostrum- and formula-fed neonatal calves. J. Nutr. 141:48-55. https://doi.org/10.3945/jn.110.128652.

Swali, A., and D. C. Wathes. 2006. Influence of the dam and sire on size at birth and subsequent growth, milk production and fertility in dairy heifers. Theriogenology 66:1173-1184. https://doi. org/10.1016/j.theriogenology.2006.03.028.

Tarry-Adkins, J. L., and S. E. Ozanne. 2011. Mechanisms of early life programming: current knowledge and future directions. Am. J. Clin. Nutr. 94:1765S-1771S. https://doi.org/10.3945/ ajcn.110.000620.

Tucker, H. A. 1981. Physiological control of mammary growth, lactogenesis, and lactation. J. Dairy Sci. 64:1403-1421.

Wathes, D. C., Z. Cheng, N. Bourne, V. J. Taylor, M. P. Coffey, and S. Brotherstone. 2007. Differences between primiparous and multiparous dairy cows in the inter-relationships between metabolic traits, milk yield and body condition score in the periparturient period. Domest. Anim. Endocrinol. 33:203-225. https://doi.org/10.1016/j. domaniend.2006.05.004.

Weber, C., C. Hametner, A. Tuchscherer, B. Losand, E. Kanitz, W. Otten, S. P. Singh, R. M. Bruckmaier, F. Becker, W. Kanitz, and H. M. Hammon. 2013. Variation in fat mobilization during early lactation differently affects feed intake, body condition, and lipid and glucose metabolism in high-yielding dairy cows. J. Dairy Sci. 96:165-180. https://doi.org/10.3168/jds.2012-5574.

Woliński, J., M. Biernat, P. Guilloteat, B. R. Weström, and R. Zabielski. 2003. Exogenous leptin controls the development of the small intestine in neonatal piglets. J. Endocrinol. 177:215-222.

Woliński, J., M. Słupecka, and K. Romanowicz. 2014. Leptin and ghrelin levels in colostrum, milk and blood plasma of sows and pig neonates during the first week of lactation. Anim. Sci. J. 85:143-149. /https://doi.org/10.1111/asj.12099.

Yamauchi, T., J. Kamon, Y. Minokoshi, Y. Ito, H. Waki, S. Uchida, S. Yamashita, M. Noda, S. Kita, K. Ueki, K. Eto, Y. Akanuma, P. Froguel, F. Foufelle, P. Ferre, D. Carling, S. Kimura, R. Nagai, B. B. Kahn, and T. Kadowaki. 2002. Adiponectin stimulates glucose utilization and fatty-acid oxidation by activating AMP-activated protein kinase. Nat. Med. 8:1288-1295. https://doi.org/10.1038/ nm788.

Yunta, C., M. Terre, and A. Bach. 2015. Short- and medium-term changes in performance and metabolism of dairy calves offered different amounts of milk replacers. Livest. Sci. 181:249-255. https:// doi.org/10.1016/j.livesci.2015.09.008. 